\title{
Seasonal cycle and long-term trend of solar energy fluxes through Arctic sea ice
}

\author{
S. Arndt and M. Nicolaus \\ Alfred-Wegener-Institut Helmholtz-Zentrum für Polar- und Meeresforschung, Bremerhaven, Bussestraße 24, \\ 27570 Bremerhaven, Germany \\ Correspondence to: S. Arndt (stefanie.arndt@awi.de)
}

Received: 28 April 2014 - Published in The Cryosphere Discuss.: 5 June 2014

Revised: 4 November 2014 - Accepted: 5 November 2014 - Published: 28 November 2014

\begin{abstract}
Arctic sea ice has not only decreased in volume during the last decades, but has also changed in its physical properties towards a thinner and more seasonal ice cover. These changes strongly impact the energy budget, and might affect the ice-associated ecosystems. In this study, we quantify solar shortwave fluxes through sea ice for the entire Arctic during all seasons. To focus on sea-ice-related processes, we exclude fluxes through open water, scaling linearly with sea ice concentration. We present a new parameterization of light transmittance through sea ice for all seasons as a function of variable sea ice properties. The maximum monthly mean solar heat flux under the ice of $30 \times 10^{5} \mathrm{Jm}^{-2}$ occurs in June, enough heat to melt $0.3 \mathrm{~m}$ of sea ice. Furthermore, our results suggest that $96 \%$ of the annual solar heat input through sea ice occurs during only a 4-month period from May to August. Applying the new parameterization to remote sensing and reanalysis data from 1979 to 2011, we find an increase in transmitted light of $1.5 \% \mathrm{yr}^{-1}$ for all regions. This corresponds to an increase in potential sea ice bottom melt of $63 \%$ over the 33-year study period. Sensitivity studies reveal that the results depend strongly on the timing of melt onset and the correct classification of ice types. Assuming 2 weeks earlier melt onset, the annual transmitted solar radiation to the upper ocean increases by $20 \%$. Continuing the observed transition from a mixed multi-year/first-year sea ice cover to a seasonal ice cover results in an increase in light transmittance by an additional $18 \%$.
\end{abstract}

\section{Introduction}

The evolution of Arctic sea ice towards a thinner, younger, and more seasonal sea ice cover during the last few decades (e.g., Comiso, 2012; Haas et al., 2008; Maslanik et al., 2007, 2011) has a strong impact on the partitioning of solar energy between the atmosphere, sea ice, and ocean (e.g., Perovich et al., 2007b, 2011a; Wang et al., 2014). Decreased surface albedo (Perovich et al., 2011a), earlier melt onset, and a longer melt season (Markus et al., 2009, updated) have contributed to the observed increases in sea ice and snow melt (Perovich and Richter-Menge, 2009), and higher absorption and transmission of solar irradiance within and through Arctic sea ice (Nicolaus et al., 2012; Stroeve et al., 2014). Beyond the physical consequences of the observed changes, strong impacts on ecological interactions and biogeochemical processes are expected, such as changes in habitat conditions for ice-associated organisms or changes in primary production (Arrigo et al., 2012; Deal et al., 2011; Popova et al., 2012).

Various studies have shown the immediate link between sea ice energy and mass balance, as well as the impact of energy fluxes on the physical properties of sea ice (Grenfell et al., 2006; Light et al., 2008; Perovich and Richter-Menge, 2009). These heat fluxes are composed of short-wave, longwave, conductive, and turbulent fluxes at the interfaces of sea ice with the atmosphere and the ocean. Beyond these energy budget approaches, sea ice mass balance may also be derived from direct comparisons of sea ice growth during winter, and surface and bottom melt during summer (Perovich et al., 2011b).

From studies on the interaction of sunlight and sea ice, it has been possible to improve our understanding of the effects 
of snow cover (Perovich et al., 2007b), melt ponds (Rösel and Kaleschke, 2012; Schröder et al., 2014), and biological interactions (Arrigo et al., 2012; Mundy et al., 2005, 2007). In addition, the spatial variability (Perovich et al., 2011a) and seasonal changes (Nicolaus et al., 2010a; Perovich et al., 2002; Perovich and Polashenski, 2012) in the optical properties of sea ice and snow have been studied by different methods. However, previous studies have not quantified large-scale, multi-seasonal, and inter-annual changes, because these studies were limited to different regions and/or seasons of the year. In addition, these studies have described measurements on different ice types, which also differ in their optical properties as a result of their growth history (Perovich and Polashenski, 2012). One possible approach obtaining such generalized studies on the in- and under-ice energy budgets in sea-ice-covered oceans would be to use a radiative transfer model in combination with surface energy budgets, as implemented by Perovich et al. (2011a). However, such a model would require adequate knowledge about the distribution of snow and sea ice (as forcing data) to derive the optical properties of sea ice and snow as a function of space and time. This type of information is not available yet, in particular not for timescales on the order of decades. An alternative approach is to use existing remote sensing and re-analysis data together with a parameterization of light transmittance through sea ice. This method was developed by Nicolaus et al. $(2012,2013)$ to calculate Arctic-wide radiation fluxes through sea ice. However, these studies were restricted to 1 month (August 2011) when comprehensive in situ measurements are available from the trans-polar cruise of German research vessel Polarstern.

In order to improve the understanding of the ongoing change in sea ice conditions and the associated impact on the partitioning of solar energy, we provide an estimate of the monthly shortwave radiative transfer through sea ice for the entire Arctic Ocean for the period 1979 to 2011. To emphasize the changing physical properties of the Artic sea ice cover, our estimates include fluxes through sea ice only. Therefore, we use a definition of 6 types of sea ice over the annual cycle, define 6 distinct time periods of insolation conditions, and include the temporal and spatial variability of melt ponds to extend and generalize the upscaling method of Nicolaus et al. (2012, 2013). In order to investigate the reliability of the method and to obtain a measure of uncertainty, we perform sensitivity studies by comparing the calculated fluxes to in situ observations obtained from the Transpolar Drift, between 86.5 and $88.5^{\circ} \mathrm{N}$, during the drift study of the schooner Tara from April to September 2007 (Nicolaus et al., 2010a). Finally, it was possible to estimate transmitted heat fluxes through sea ice and to derive trends for the entire Arctic basin for the period of 1979 to 2011. Since this study focuses on the variability of sea ice properties, changes in sea ice concentrations are not considered.

\section{Methods}

Solar short-wave radiation fluxes ( 250 to $2500 \mathrm{~nm}$, here also referred to as "light") through sea ice are calculated daily, from 1 January 1979 to 31 December 2011, for the entire Arctic Ocean (north of $65^{\circ} \mathrm{N}$ ). Building on the method and parameterization by Nicolaus et al. $(2012,2013)$, which were limited to the snow-free summer season in 2011 without any seasonal cycle of surface properties, the parameterization of light transmittance through sea ice has been extended for all seasons. Thus, transmittance is now estimated as a function of surface (snow) melt/freeze state and melt pond concentration, in addition to the previous (only) sea ice age dependence. The new parameterization was driven by satellite observations of daily sea ice concentration and surface solar irradiance to calculate fluxes as performed in Nicolaus et al. $(2012,2013)$. All data sets are interpolated to a $10 \mathrm{~km}$ polar stereographic grid, using nearest-neighbor resampling. Although daily fluxes are calculated and available, only monthly means are shown and used to discuss the findings, because the main focus of this extended study is on seasonal changes and long-term trends.

For the main analyses, we exclude open water areas, as those would clearly dominate the transmitted heat flux signal (Perovich et al., 2007a). Therefore, we consider only fluxes through ice-covered areas, as these are crucial for the energy and mass balance of sea ice as well as for biological processes beneath the ice cover. The solar heat input to the open ocean also has an important impact on the ice-ocean system, but is a basic function of sea ice concentration.

\subsection{Solar heat flux equations}

Solar heat input through sea ice into the ocean $\left(E_{\mathrm{T}}(t, x, y)\right)$ is calculated as the product of the downward solar radiation $\left(E_{\mathrm{d}}\right)$, the sea ice concentration $\left(C_{\mathrm{i}}\right)$, and the total transmittance of pond-covered sea ice $\left(\tau_{\mathrm{i}}\right)$ for each grid cell and each day, over the period 1 January 1979 to 31 December 1999:

$E_{\mathrm{T}}(t, x, y)=E_{\mathrm{d}}(t, x, y) \cdot C_{\mathrm{i}}(t, x, y) \cdot \tau_{\mathrm{i}}$,

with time $(t)$ and position $(x, y)$.

Since 1 January 2000, when satellite-derived melt-pond concentrations are available, the solar heat input through sea ice into the ocean $\left(E_{\mathrm{T}}\right)$ has been calculated as the sum of fluxes through bare ice $\left(E_{\mathrm{B}}\right)$ and melt ponds $\left(E_{\mathrm{P}}\right)$ :

$$
\begin{aligned}
& E_{\mathrm{T}}(t, x, y)=E_{\mathrm{B}}(t, x, y)+E_{\mathrm{P}}(t, x, y) \\
& \begin{aligned}
E_{\mathrm{T}}(t, x, y) & =E_{\mathrm{d}}(t, x, y) \cdot C_{\mathrm{i}}(t, x, y) \cdot\left[1-C_{\mathrm{p}}(t, x, y)\right] \\
& \cdot \tau_{\mathrm{b}}(t, x, y)+E_{\mathrm{d}}(t, x, y) \cdot C_{\mathrm{i}}(t, x, y) \\
& \cdot C_{\mathrm{p}}(t, x, y) \cdot \tau_{\mathrm{p}}(t, x, y),
\end{aligned}
\end{aligned}
$$

with the transmitted solar radiation at the bottom of the ice $E_{\mathrm{T}}$, downward solar radiation $E_{\mathrm{d}}$, sea ice concentration $C_{\mathrm{i}}$, 


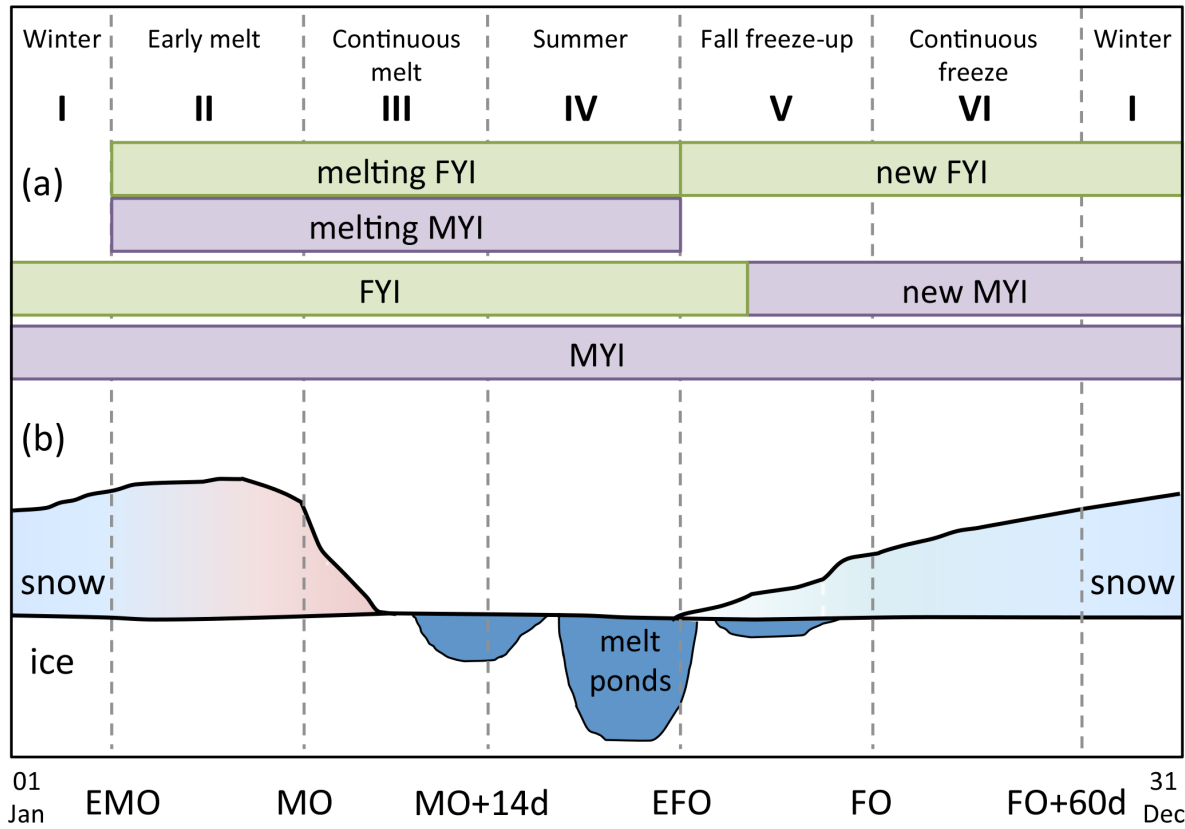

Figure 1. Classification of sea ice (a) types and (b) surface properties as used in this study. The timing of each phase results from the status of the sea ice. Depending on the season, different sea ice types co-exist. Abbreviations: FYI: first-year ice; MYI: multi-year ice; EMO: early melt onset; MO: melt onset; EFO: early freeze onset; FO: freeze onset.

melt pond fraction $C_{\mathrm{p}}$, transmittance of bare sea ice $\tau_{\mathrm{b}}$, transmittance of melt ponds $\tau_{\mathrm{p}}$, time $t$, and grid cell $(x, y)$.

To obtain the total solar heat input per unit area for a certain time period $\left(Q_{\mathrm{T}}(x, y)\right)$, the heat flux is calculated for each grid cell and then integrated over the given time $(\Delta t)$ :

$Q_{\mathrm{T}}(x, y)=\sum E_{\mathrm{T}}(t, x, y) \Delta t$.

Spatial integration over the entire Arctic Ocean (north of $65^{\circ} \mathrm{N}$ ) reveals the Arctic-wide total solar heat input $Q_{\mathrm{T}}$.

Assuming sea ice is at its melting point, has a density $\rho_{\text {ice }}$ of $917 \mathrm{~kg} \mathrm{~m}^{-3}$, and has a latent heat of fusion $L_{\text {ice }}$ of $0.3335 \mathrm{~J} \mathrm{~kg}^{-1}$, and that there are no changes in long-wave, latent, and conductive heat fluxes, $Q_{\mathrm{T}}(x, y)$ can be converted into a sea ice melt rate $m_{\text {eq }}$ :

$m_{\mathrm{eq}}=\frac{Q_{\mathrm{T}}(x, y)}{L_{\mathrm{melt}} \cdot \rho_{\mathrm{ice}}}$.

\subsection{Seasonality of surface properties and transmittance of Arctic sea ice}

To calculate solar heat fluxes under Arctic sea ice for an entire year, the main challenge is to parameterize the seasonal evolution of $\tau_{\mathrm{b}}(t, x, y)$. This is mainly achieved by merging the sea ice age information (Maslanik et al., 2007, 2011) with the melt/freeze status (Markus et al., 2009, updated) into six surface types.

\subsubsection{Definition of sea ice types}

Figure 1 shows the annual cycle of these six sea ice classes together with surface properties of Arctic sea ice. These classes are introduced to avoid abrupt changes in the optical properties during the transition from spring to summer as well as from summer to fall. After early melt onset (EMO), melting FYI and melting MYI are introduced for sea ice completely melting during the summer melt. Therefore, it is necessary to classify each cell as either becoming ice free (sea ice concentration of less than $15 \%$ ) or not. To do this, the ice concentration of each pixel is evaluated for all days until EFO. If the pixel becomes ice free, the last day of melting is stored for later calculations. According to Maslanik et al. (2007, 2011), FYI surviving the summer melt turns into MYI after week 36 of the year. As the immediate change in ice age tagging is not associated with an immediate change in sea ice properties, we include an additional class of new $M Y I$ that turns into MYI at the end of the year. When sea ice concentration reaches a value greater than $15 \%$, the pixel is classified as new FYI.

In the following, sea ice consisting of both bare sea ice and melt ponds is called pond-covered sea ice.

\subsubsection{Transmittance of pond-covered sea ice}

The seasonal evolution of surface properties and the transmittance of Arctic sea ice is divided into six different phases (note that there are both different ice types and different seasonal phases). The timing of these phases is based on the 

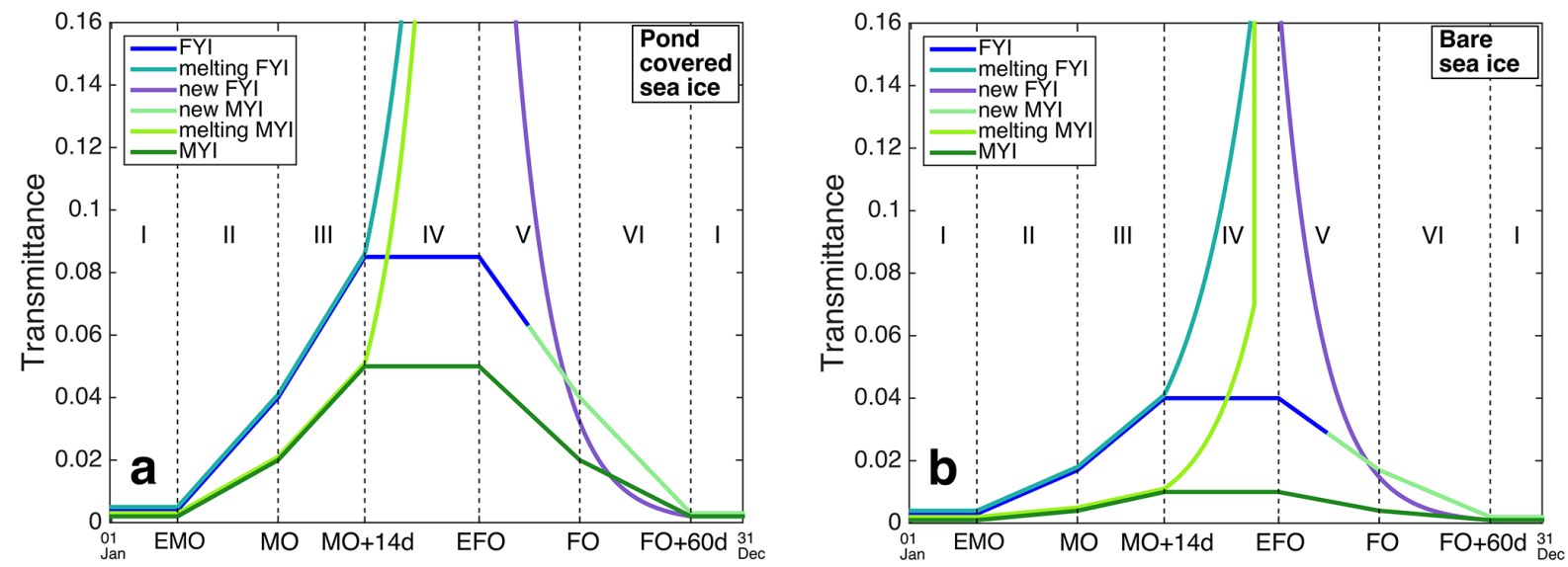

Figure 2. (a) Total transmittance of sea ice during each phase (Fig. 1). In this figure, melt pond concentrations of $26 \%$ are assumed for firstyear ice (FYI) and $29 \%$ are assumed for multi-year ice (MYI). (b) Transmittance of bare ice during each phase (see Fig. 1). Transmittance values for single ice classes are given in Table 1 . The illustrated evolution of transmittance values is based on analyses from previous field campaigns and observations. Abbreviations: see Fig. 1.

melt and freeze onset data established by Markus et al. (2009, updated). Our parameterization of seasonal variations in light transmittance considers the transmission through both sea ice and snow, and is mostly based on the results of two field campaigns that focused on the understanding of ice-ocean-atmosphere processes that control the partitioning of solar radiation between reflection, absorption, and transmittance: the Surface Heat Budget of the Arctic Ocean (SHEBA) experiment from 1997 to 1998 (Perovich, 2005), and measurements conducted on MYI within the Transpolar Drift, between 86.5 and $88.5^{\circ} \mathrm{N}$, during the drift study of the schooner Tara from April to September 2007 (Nicolaus et al., 2010a). In addition, analyses from previous observations by Perovich (1996), Perovich et al. (1998), and Nicolaus et al. (2010b) are used. Figure 2a shows the seasonal total transmittance of pond-covered sea ice $\left(\tau_{\mathrm{i}}\right)$ for constant pond concentrations of 26 (FYI) and 29\% (MYI), respectively, used for the period 1979 to 2000 , during which time there are no available satellite melt pond coverage observations. This combination of a given mixture of ponds and bare ice was used to develop the seasonal cycle of transmittance, as described in the next paragraphs. All transmittance values for the different phases are compiled in Table 1.

\section{Phase I: winter (from FO + 60 days to EMO)}

Winter conditions are characterized by snow-covered sea ice without melt ponds. The snow cover is assumed to be cold, dry and optically thick, which means the snow determines the optical properties. Thus, radiative fluxes through sea ice are small. The best available transmittance observations for such conditions are those measured during the first days of the Tara drift, although it was already early April. Hence, transmittance was accordingly set to 0.002 (Nicolaus et al., 2010a).

\section{Phase II: early melt (from EMO to MO)}

EMO denotes the first significant change in optical properties. Snow depth decreases, and surface and sea ice temperatures increase. Consequently, the snow becomes wet and is no longer optically thick. This phase also corresponds to formation of the first melt ponds. Here we assume a linear increase in $\tau_{\mathrm{i}}$ until MO.

Nicolaus et al. (2010a) calculated a transmittance of 0.02 for MYI for the day of MO. Furthermore, Perovich and Polashenski (2012) reveal that the surface albedo of FYI is about half that of MYI at the same time. Adapting this albedo evolution to the transmittance, the transmittance of FYI is assumed to be 0.04 at MO.

\section{Melting FYI and melting MYI}

After EMO, the continued melt of snow and sea ice strongly impacts light transmittance. Starting with the summer phase (Phase IV), we assume that the optical properties of melting sea ice differ from sea ice surviving the summer melt. In addition, differences between melting FYI and melting MYI are expected. Therefore, melting FYI and melting MYI are separated in the parameterization of $\tau_{\mathrm{i}}$.

In order to describe these classes, laboratory studies by Perovich (1996) on the evolution of albedo during the initial ice growth phase were applied to the evolution of transmittance, assuming an inverse behavior of transmittance and albedo. Therefore, the increase in transmittance of seasonal sea ice can be described as roughly exponential (Perovich, 1996). Assuming the transition of transmittance from melting sea ice to the open ocean is the inverse of the albedo transition (Perovich, 1996), we use a transmittance of 0.4 for the last remaining sea ice. Thus, an exponential increase between the first and last day of melting for the corresponding 
pixel is fitted, and the maximum transmittance of sea ice is expected to be 0.4 .

\section{Phase III: continuous melt (from MO to MO+ 14 days)}

After MO, snow is assumed to melt completely within 14 days (Nicolaus et al., 2006; Perovich et al., 2002), and pond cover fraction increases rapidly until the maximum pond cover is reached at the end of this phase (Nicolaus et al., 2010a). The transmittance continues to increase linearly until the beginning of summer (MO + 14 days).

\section{Phase IV: summer (from MO + 14 days to EFO)}

During this phase, the sea ice surface is characterized by strong sea ice melt and culminates in the minimum ice concentration of each pixel. The surface is a mixture of bare ice and melt ponds with a constantly renewing surface scattering layer (Perovich et al., 2002; Barber et al., 1998). This implies small changes in the optical properties and light transmittance of the ice over time during Phase IV. Hence, $\tau_{\mathrm{i}}$ is assumed to be constant for sea ice that survives summer melt. Based on observed transmittance values of solar radiation through FYI and MYI during TransArc 2011 (Nicolaus et al., 2012), we use summer transmittance values of 0.04 for bare FYI, 0.01 for bare MYI, 0.22 for melt ponds on FYI, and 0.15 for melt ponds on MYI. These values are weighted according to melt pond fractions (Rösel and Kaleschke, 2012).

\section{Phase V: fall freeze-up (from EFO to FO)}

Air and surface temperatures drop below $0{ }^{\circ} \mathrm{C}$, resulting in the initial occurrence of surface freezing. Subsequently, snow accumulation can begin and former melt ponds refreeze, but can still be recognized through the new snow cover. Thus, the transmittance is decreasing rapidly. Similar to Phase III, the transmittance of FYI decreases to 0.04 and, for MYI, to 0.02 until FO. Additionally, sea ice that survives the summer melt is promoted to 1-year older ice in weeks 36-37 according to Maslanik et al. (2007), and new ice forms. The transmittance of new first-year ice evolves correspondingly to the melting sea ice surface described above. From EFO until the beginning of winter (FO +60 days), the strong growth of sea ice (e.g., increasing sea ice thickness) results in an exponential decrease in light transmission through newly formed FYI.

\section{Phase VI: continuous freeze (from FO to FO + 60 days)}

This phase is characterized by continuous freezing, increasing snow accumulation towards an optically thick snow layer, and the gradual disappearance of melt ponds. In addition to new sea ice formation, the existing sea ice is getting thicker and older, and deformation is increasing. Transmittance decreases back to 0.02 by winter. It is assumed that at the end of the freezing phase (FO +60 days), the surface properties of all newly formed FYI can be considered to be equivalent.
Afterwards, the accumulated optically thick snow layer again dominates the optical properties of FYI and MYI (Phase I).

\subsubsection{Transmittance of bare ice and ponds}

For the period after the year 2000, when satellitederived melt pond products are available from Rösel and Kaleschke (2012), the transmittance values of bare ice $\left(\tau_{\mathrm{b}}\right)$ and ponds $\left(\tau_{\mathrm{p}}\right)$ are treated separately (Fig. $2 \mathrm{~b}$ ). The modal transmittance of melt ponds is constant over the entire melt season. It is set to 0.22 for FYI and 0.15 for MYI, as measured during TransArc 2011 (Nicolaus et al., 2012). The seasonal evolution of transmittance for bare ice $\left(\tau_{\mathrm{b}}\right)$ follows the transmittance for pond-covered sea ice $\left(\tau_{\mathrm{i}}\right)$ :

$\tau_{\mathrm{b}}(x, y)=\tau_{\mathrm{i}}(x, y) \cdot \frac{\tau_{\mathrm{b}}(\text { summer, } x, y)}{\tau_{\mathrm{i}}(\operatorname{summer}, x, y)}$.

The values of $\tau_{\mathrm{b}}$ (summer, $x, y$ ) and $\tau_{\mathrm{i}}$ (summer, $x, y$ ) are the constant values during summer as given in Table 1 . Thus, the ratio of both is constant for MYI (0.20) and FYI (0.46). Finally, those transmittance values are scaled with the pond concentrations, as given in Eq. (2).

\subsection{Deriving trends}

Based on the calculated results of the solar heat input through sea ice into the ocean, trends are analyzed for the period 1979 to 2011. The trends (monthly and annual) are calculated by a linear least-squares fit of the total mean (monthly or annual) heat flux for each grid cell $Q_{\mathrm{T}}(x, y)$. Resulting trends are normalized by trends in sea ice concentration, because here we focus on radiative fluxes through the ice-covered part of the ocean. Otherwise, the results would depend strongly on regional and temporal trends in sea ice concentration, because of the high transmittance (0.93) of open water. All trends were calculated for both the annual mean ice-covered area in 2011 and the monthly mean ice-covered area in 2011 (sea ice concentration $>15 \%$ ) to allow for a representative comparison. Regions that were not ice covered at any time in 2011 are excluded from the main analysis and discussion.

\subsection{Input data sets}

The following satellite and re-analyses data sets were used (Table 2):

1. Sea ice concentration observations were obtained from the Special Sensor Microwave Imager (SSMI/S) provided through the Ocean and Sea Ice Satellite Application Facilities (OSI SAF, product ID OSI-401, Andersen et al., 2007). For this study, a combination of reprocessed data (1979 to 2007) and operational data (2008 to 2011) was used. Both data sets have systematic differences due to processing with a different set of tie point statistics for the ice concentration algorithm (Lavergne et al., 2010). However, within the 
Table 1. Transmittance values of different sea ice and surface types. Abbreviations: FYI: first year ice; MYI: multi-year ice; Phase I: winter; MO: melt onset; Phase IV: summer; FO: freeze onset; Threshold: transition from open ocean to sea ice and vice versa.

\begin{tabular}{llllll}
\hline & $\begin{array}{l}\text { Phase I } \\
\text { (winter) }\end{array}$ & At MO & $\begin{array}{l}\text { Phase IV } \\
\text { (summer) }\end{array}$ & At FO & Threshold \\
\hline FYI, pond-covered sea ice & 0.002 & 0.04 & 0.087 & 0.04 & 0.4 \\
MYI, pond-covered sea ice & 0.002 & 0.02 & 0.05 & 0.02 & 0.4 \\
FYI, bare ice/snow & 0.001 & 0.017 & 0.04 & 0.017 & 0.17 \\
MYI, bare ice/snow & 0.0 & 0.004 & 0.01 & 0.004 & 0.07 \\
\hline FYI, melt ponds & & & 0.22 & & \\
MYI, melt ponds & & & 0.15 & & \\
Open ocean & & & 0.93 & & \\
\hline
\end{tabular}

Table 2. Data sources of the different parameters used in this study.

\begin{tabular}{lll}
\hline Parameter & Time period & Source \\
\hline Sea ice concentration & $1979-2007$ & OSI SAF, reprocessed data \\
& $2008-2011$ & OSI SAF, operated data (Andersen et al., 2007) \\
\hline Sea ice age & $1979-2011$ & Maslanik et al. (2007, 2011) \\
\hline Downward surface solar radiation & $1979-2011$ & ECMWF (Dee et al., 2011) \\
\hline Melt and freeze onset & $1979-2005$ & SSMR \\
& $2006-2010$ & AMSR-E \\
& 2011 & SSM/IS (Markus et al., 2009) \\
\hline Melt pond fraction & $1979-1999$ & Constant fraction as in 2011 \\
& $2000-2011$ & ICDC (Rösel et al., 2012) \\
\hline
\end{tabular}

documented uncertainties, both data sets build the best available and consistent time series of sea ice concentration. There is no consistent uncertainty for the data product, but different approaches for determining uncertainties are described in Lavergne et al. (2010).

2. For sea ice age, we used the updated data product by Maslanik et al. (2007, 2011). This product has been available since 1979, and is based on satellitederived ice motion data calculated from different sensors using a Lagrangian feature tracking algorithm. Although this data product distinguishes ice ages between 1 and 10 years, here we only distinguish FYI and MYI (2 years and older), because all MYI is assumed to have similar optical properties. All data points with a sea ice concentration of greater than 0 but without an assigned sea ice age class were treated as FYI. Vice versa, all data points with sea ice concentration of greater than $15 \%$ but which had an assigned sea ice age class were treated as open water. Such modifications were necessary to obtain consistent data products from the different sources, indicating partially varying sea ice extents. The ice age data set represents a 7-day average of either FYI or MYI without any uncertainty estimates. However, uncertainties in sea ice concentration and drift will have an impact on the ice age data.

3. Downward surface solar radiation data were obtained four times per day from the European Centre for Medium-Range Weather Forecast (ECMWF) EraInterim re-analyses (Dee et al., 2011; Lindsay et al., 2014). The data (four values per day) were averaged to daily means and have been available since 1979 . Uncertainties for the data set are not reported.

4. Sea ice surface characteristics were categorized by melt and freeze onset dates from passive microwave data (1979 to 2012) (Markus et al., 2009, updated). The data set distinguishes between the first occurrence of a melt event (early melt onset, EMO), the following continuous melt (melt onset, MO), the first occurrence of freeze-up conditions (early freeze onset, EFO), and the day of persistent freezing conditions (freeze onset, FO). The standard deviations, assumed as uncertainties, for the given dates are reported as $\mathrm{EMO} \pm 3.6$ days, $\mathrm{MO} \pm 3.7$ days, $\mathrm{EFO} \pm 4.5$ days, and $\mathrm{FO} \pm 4.0$ days (Markus et al., 2009, updated).

5. Melt pond fraction was used from Rösel et al. (2012), retrieved from the Moderate Resolution Imaging 

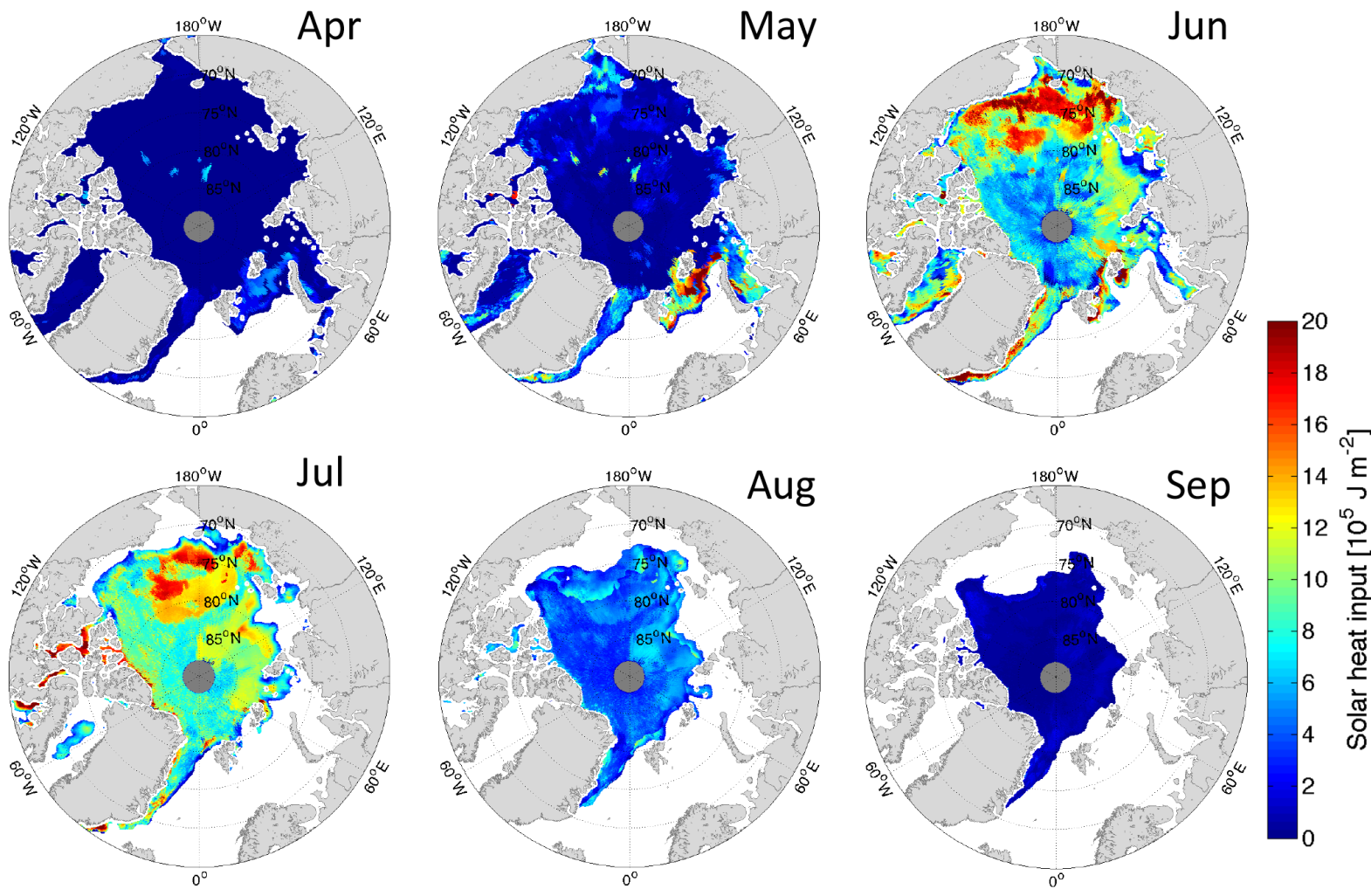

Figure 3. Monthly mean of total solar heat input $\left(Q_{\mathrm{T}}(x, y)\right)$ under Arctic sea ice (ice-covered areas only) for the year 2011.

Spectroradiometer (MODIS) onboard NASA's Terra and Aqua satellites. As this data set has only been available since 2000, melt pond fractions from 1979 to 1999 were set to constant summer mean values of $26 \%$ for FYI and $29 \%$ for MYI, as given in Rösel et al. (2012) for August 2011. In order to maintain the consistency of the surface characteristics, all melt pond fractions before EMO are set to zero. The mean standard deviation from 2000 to 2011, assumed as uncertainty, is calculated as $\pm 3 \%$ for FYI and MYI.

We do not include snow depth and sea ice thickness as input data sets due to the lack of consistent high temporal resolution and long-term data products. Limitations of using sea ice age as an indirect proxy for ice thickness and snow cover as well as potential other approaches for the estimation of transmitted heat fluxes are discussed below.

\section{Results}

\subsection{Seasonal cycle of solar radiation under Arctic sea ice in 2011}

Based on the availability of all input data sets and the seasonality of transmittance values, the solar heat input through sea ice into the ocean is analyzed from 1979 to 2011. Figure 3 shows monthly mean heat input $\left(Q_{\mathrm{T}}(x, y)\right.$, Eq. 3 ) under
Arctic sea ice (ice-covered areas only) from April to September 2011. The exemplary year of 2011 was selected to ensure a representative comparison with previous studies conducted in August 2011 by Nicolaus et al. (2012, 2013). From October to March, the monthly mean solar radiation under sea ice was less than $0.2 \times 10^{5} \mathrm{Jm}^{-2}$, with an Arctic-wide total under-ice heat flux $\left(Q_{\mathrm{T}}\right)$ of up to $0.4 \times 10^{19} \mathrm{~J}$. Since this represents less than $1 \%$ of the annual Arctic-wide heat flux of $53.3 \times 10^{19} \mathrm{~J}$ (Eq. 3), the months October to March are omitted from further analyses and discussion. In April, the mean heat flux increased to $0.4 \times 10^{5} \mathrm{Jm}^{-2}$, with a maximum of 7 to $8 \times 10^{5} \mathrm{Jm}^{-2}$; this amount of energy is equivalent to mean ice melt rates between 7 to $8 \mathrm{~cm}$ per month (Eq. 4) in the marginal ice zone east of Spitsbergen. The transmittance triples from 0.005 in April to 0.015 in May, and together with increasing surface fluxes, the $Q_{\mathrm{T}}(x, y)$ increased from $1.0 \times 10^{19} \mathrm{~J}$ to $5.5 \times 10^{19} \mathrm{~J}$ during this time. The Barents Sea showed a mean transmitted heat flux of $2.2 \times 10^{5} \mathrm{Jm}^{-2}$ for the month of May, with a maximum value of $25 \times 10^{5} \mathrm{Jm}^{-2}$, which corresponds to a maximum sea ice melt of $25 \mathrm{~cm}$ per month. May to June showed the most pronounced monthly increases in $Q_{\mathrm{T}}(x, y)$ of $9.3 \times 10^{5} \mathrm{Jm}^{-2}$ and a transmittance of 0.054 for the entire Arctic. The maximum $Q_{\mathrm{T}}(x, y)$ was $30 \times 10^{5} \mathrm{Jm}^{-2}$ in June, with a corresponding maximum melt rate of approximately $30 \mathrm{~cm}$ per month. June also had the highest $Q_{\mathrm{T}}\left(20.9 \times 10^{19} \mathrm{~J}\right)$, which 

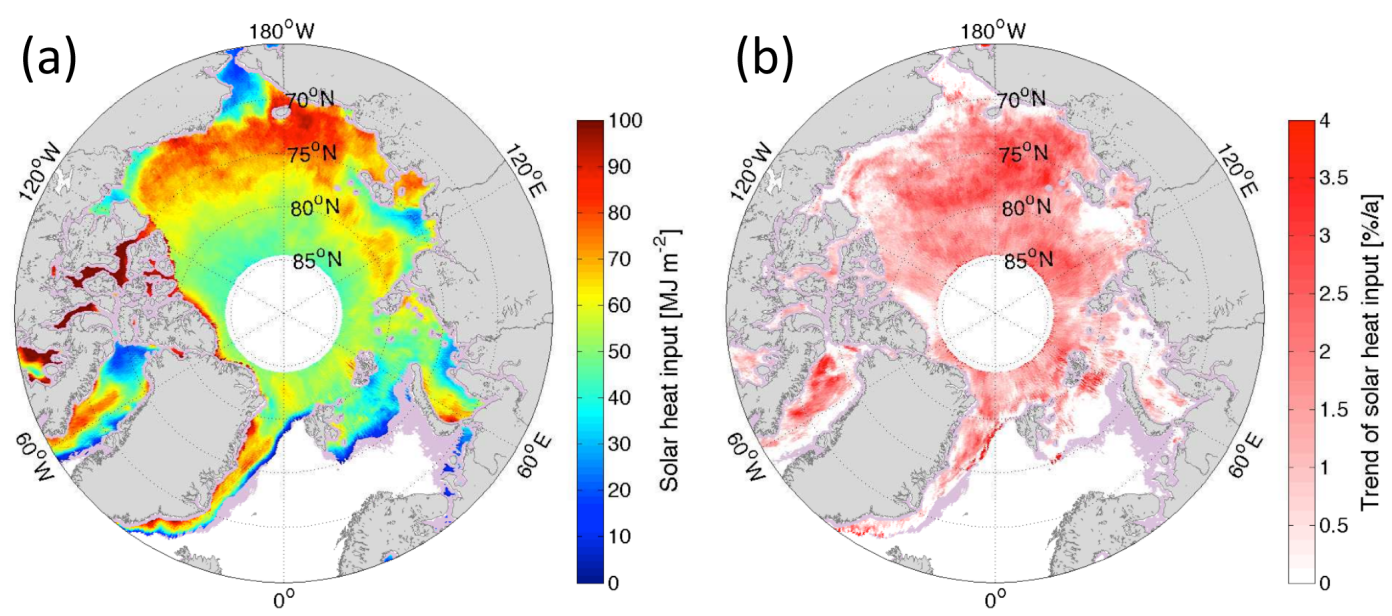

Figure 4. Annual total solar heat input $\left(Q_{\mathrm{T}}(x, y)\right)$ through Arctic sea ice. (a) Average and (b) trend from 1979 to 2011. The trend is normalized for the trend in sea ice concentration. Purple shaded areas were not covered with sea ice during the maximum extent in all years.

was associated with the highest surface solar irradiance over the entire Arctic Ocean $\left(851 \times 10^{19} \mathrm{~J}\right)$. This increase in solar irradiance was linked to the beginning of the melt phase (mean MO on 30 May 2011) and the associated rapid snow melt. During this time, the difference between thin melting sea ice along the sea ice edge and the persistent sea ice cover became most obvious, e.g., in the Chuckchi and Beaufort seas. In July, Arctic-wide averaged $Q_{\mathrm{T}}(x, y)$ reached its annual maximum of $9.8 \times 10^{5} \mathrm{Jm}^{-2}$. This resulted primarily from the annual maximum in mean transmittance of 0.089 , and led to a monthly flux $Q_{\mathrm{T}}$ of $18.4 \times 10^{19} \mathrm{~J}$. The impact of the different optical properties $\left(\tau_{\mathrm{i}}\right)$ of MYI and FYI became most obvious in July, because the difference in both values is at its maximum. In addition, the strong decrease in sea ice concentration along the ice edge became more important for the under-ice heat fluxes, because light transmittance increased strongly in these regions. The August decrease in $Q_{\mathrm{T}}(x, y)$ by more than $50 \%$ to $4.4 \times 10^{5} \mathrm{Jm}^{-2}$, along with only a slight reduction in transmittance to 0.084 , can be explained by the strong decrease in surface solar irradiance $\left(679 \times 10^{19} \mathrm{~J}\right)$. These surface fluxes are only half of those calculated for previous months. August maximum $Q_{\mathrm{T}}(x, y)$ reached up to $19 \times 10^{5} \mathrm{Jm}^{-2}$. In September, the $Q_{\mathrm{T}}(x, y)$ decreased further to $0.6 \times 10^{5} \mathrm{Jm}^{-2}$, which can be related to a low transmittance of 0.039 and $Q_{\mathrm{T}}$ of $0.7 \times 10^{19} \mathrm{~J}$.

\subsection{Light transmission from 1979 to 2011}

The new data set of $Q_{\mathrm{T}}(x, y)$ allows quantification of annual budgets, regional differences, and decadal trends. Figure 4a shows the averaged annual solar heat input through sea ice into the ocean $\left(Q_{\mathrm{T}}(x, y)\right)$, and illustrates therefore the strong regional variability of $Q_{\mathrm{T}}(x, y)$, ranging from 20 to $100 \mathrm{MJ} \mathrm{m}^{-2}$ for the given period. This range in heat fluxes is equivalent to an ice melt rate of 24 to $120 \mathrm{~cm} \mathrm{yr}^{-1}$. The mean total solar heat input transmitted

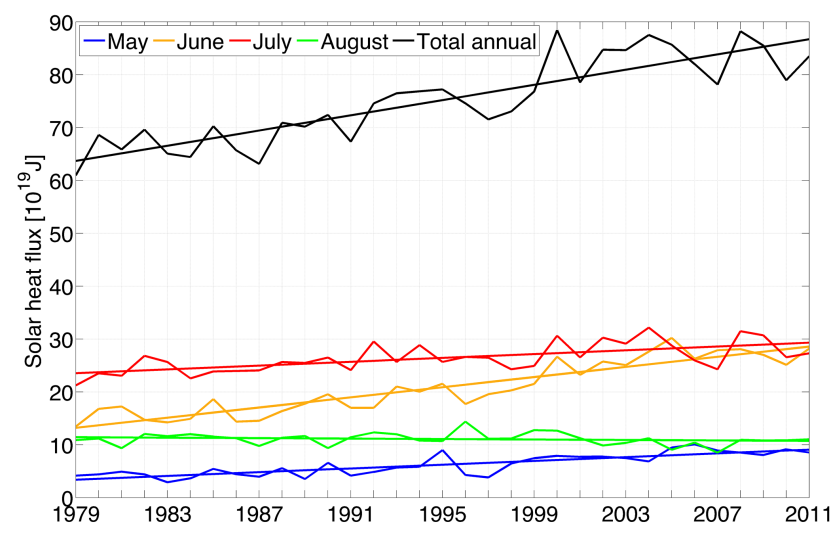

Figure 5. Arctic-wide total solar heat flux under sea ice $\left(Q_{\mathrm{T}}\right)$ (black) and monthly Arctic-wide solar heat input for May to August (colored) and its trend from 1979 to 2011. The data are corrected for the trend in sea ice concentration. Areas that were not ice covered at any time in 2011 or during a certain month in 2011 are excluded from the analyses.

through the considered sea-ice-covered area (Sect. 2.3) was $46 \mathrm{MJ} \mathrm{m}^{-2}$. The maximum $Q_{\mathrm{T}}(x, y)$ occurs at the edge of the marginal ice zone in the Canadian Arctic Archipelago (up to $110 \mathrm{MJ} \mathrm{m}^{-2} / 130 \mathrm{~cm}$ melt per year) and the East Siberian and Chukchi seas (up to $80 \mathrm{MJ} \mathrm{m}^{-2} / 94 \mathrm{~cm}$ melt per year). In contrast, excluding areas characterized by a strong spring sea ice retreat and a corresponding low sea ice concentration, the minimum $Q_{\mathrm{T}}(x, y)$ was found in the central Arctic, an MYIdominated region of low transmittance.

The mean trend of $Q_{\mathrm{T}}(x, y)$ was $1.5 \% \mathrm{a}^{-1}$ (excluding areas with a strong spring sea ice retreat), with a maximum of $+4 \% \mathrm{a}^{-1}$ in the East Siberian Sea and the southern part of the North American and Russian Arctic Basin (Figs. 4b and 5a). This trend translates to a $63 \%$ increase in the potential sea ice melt over the 33 -year observation period. This 
is likely due to the prolongation of the melt season in the same regions. According to a linear regression from 1979 to 2011 for the entire Arctic, the mean MO was 4 days earlier, shifting from day 145 (24 May) to day 141 (20 May). The strongest trend of $4.8 \times 10^{18} \mathrm{~J} \mathrm{a}^{-1}$ was found for June, followed by May and July with $1.8 \times 10^{18} \mathrm{~J} \mathrm{a}^{-1}$. August shows a comparably weak negative trend of $-0.2 \times 10^{18} \mathrm{~J} \mathrm{a}^{-1}$. Assuming an identical sea ice extent in 1979 and 2011, the increase in the annual mean solar heat flux through sea ice $\left(Q_{\mathrm{T}}\right)$ amounts to $22.5 \times 10^{19} \mathrm{~J}$ for the entire Arctic over the full study period. This corresponds to an average increase of $33 \%$. Overall, $94 \%$ of the total annual solar heat input through Arctic sea ice was observed during the four key months: May to August. Furthermore, heat flux time series (annual, June, July) show an increasing variability after 1999 (Fig. 5).

\section{Discussion}

\subsection{Seasonality and trends of transmitted fluxes}

The total annual solar radiation under Arctic sea ice was estimated to be $53.3 \times 10^{19} \mathrm{~J}$ in 2011 . Based on this, May to August are the most important months for the radiative energy partitioning. During this period, $96 \%\left(51.2 \times 10^{19} \mathrm{~J}\right)$ of the total annual solar heat input is transmitted through the sea ice. Extending the period to April to September amounts to $99 \%\left(52.9 \times 10^{19} \mathrm{~J}\right)$ of the total annual flux being transmitted within only a 6-month period. Generalizing the monthly fluxes, the annual cycle can be summarized in three phases: (1) the heat input through snow and sea ice into the ocean is negligible between October and March, (2) surface solar radiation dominates the under-ice light conditions from April to June, because transmittance increases only slowly, while surface irradiance determines most of the observed changes and variability, and (3) during summer (July to September), energy fluxes depend mainly on the sea ice type, showing large differences in transmittance between FYI and MYI.

Comparing our results to the development of the solar heat input into the ice presented by Perovich et al. (2011a, Fig. 2), both the solar heat input to the upper ocean and the solar heat input to the sea ice demonstrated a positive annual trend of 1 to $1.5 \% \mathrm{yr}^{-1}$ during the last decades. The increasing energy in the ice and upper ocean might both lead to a stronger sea ice melt. Therefore, the radiative heating of the upper ocean might contribute to a higher conductive ocean heat flux to the ice. This increase in bottom melt is affecting the sea ice mass balance. An increasing light absorption of Arctic sea ice due to more seasonal ice and less multi-year ice was also found by Nicolaus et al. (2012).

The trend towards more light transmission through sea ice does not only impact the light conditions right at the bottom of the sea ice, but also affects the horizontal and vertical light field in the ice-covered ocean. More light at the bottom of sea ice will deepen the euphotic zone, as more light penetrates deeper into the ocean (Frey et al., 2011; Katlein et al., 2014). More light can contribute to an increase in mixed layer temperature, and provide more energy for primary production and biogeochemical processes in and beneath the sea ice. However, it has to be noted that an increase in light availability does not necessarily increase biological activity, and might also be harmful (Leu et al., 2010).

An increase in transmittance will accelerate internal and bottom melt, which in turn will reduce the thickness of sea ice and increase transmittance. That feedback process can trigger a transmittance-melt feedback.

All presented trends are normalized with the trend in sea ice concentration (Sect. 2.3). Thus, changes related to physical properties of the sea ice are highlighted instead of changes related to a general sea ice retreat. Fluxes through the ice-covered ocean will be of great importance, and are much more difficult to assess than fluxes through open water. However, including the trend in sea ice concentration, the annual trend of transmitted solar heat fluxes to the upper ocean decreases from +1.5 to $\pm 1.1 \% \mathrm{a}^{-1}$. The negative trend in the open ocean heat input is evident in areas of ice motion causing an increase in ice concentration, which was also shown in Perovich et al. (2007a, 2011a). This comparison emphasizes the dominance of the albedo feedback mechanism and the strong influence of the trend in sea ice concentration on the heat budget of the entire system.

Beyond this, it is also important to consider that the trends in sea ice concentration differ significantly during different months. While it is largest $\left(-0.1 \% \mathrm{a}^{-1}\right)$ in September, it is only $-0.06 \% \mathrm{a}^{-1}$ in June, and even positive in April and May $\left(+0.04 \% \mathrm{a}^{-1}\right)$. This means that the effect of increasing transmission through open water is particularly strong in September, but less pronounced in June, when the highest absolute fluxes are observed, or in spring, when the impact on biological primary production is expected to be strongest (Wassmann and Reigstad, 2011).

\subsection{Comparison with field data}

Validation of the calculated trends and spatial variability is nearly impossible, as insufficient field data with adequate spatial and temporal coverage are available. However, some comparisons with time series of light transmission from different field studies may be performed to identify major uncertainties.

Here, we compare the surface and transmitted solar irradiance of the presented method with in situ measurements during the Transpolar Drift of Tara from 29 April to $28 \mathrm{Au}-$ gust 2007 (Nicolaus et al., 2010a). Nearest-neighbor grid points within $0.5^{\circ}$ of the daily Tara position were extracted from the presented data set and averaged. Figure 6a (red and green lines) shows a comparison of the time series for transmitted solar irradiance from both data sets. Until 8 June, the transmitted solar irradiance under sea ice varied only slightly, 


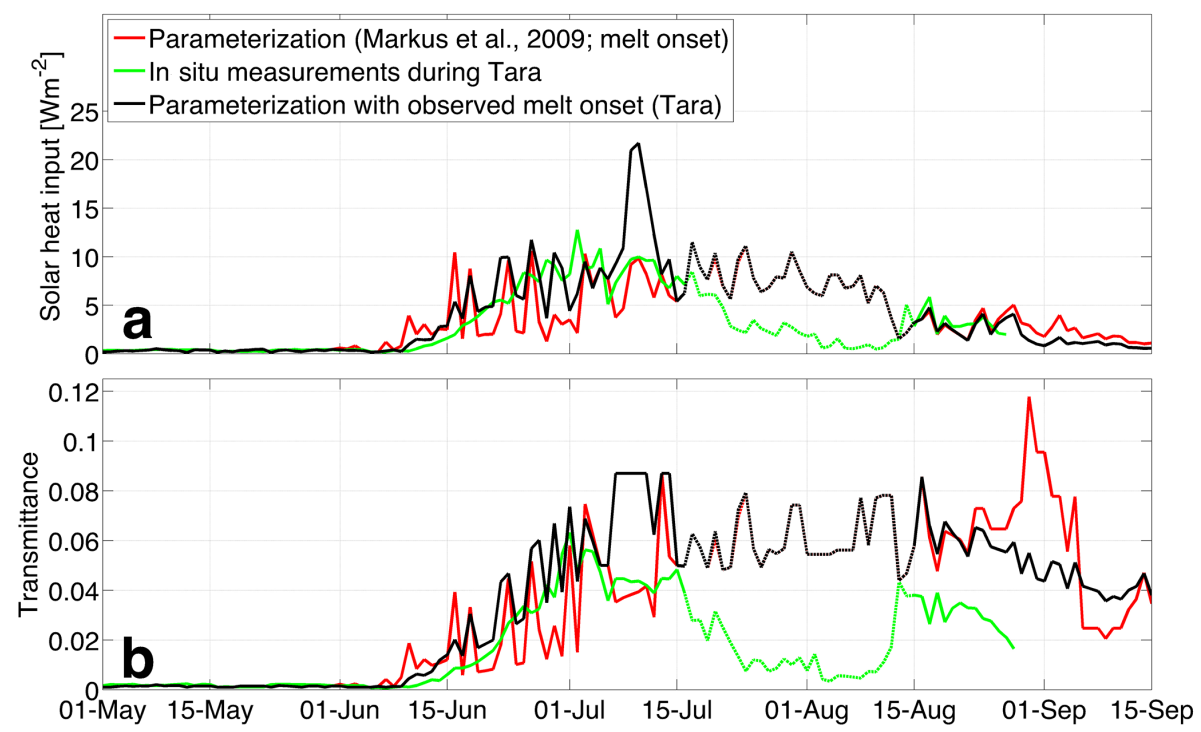

Figure 6. (a) Transmitted total solar heat input and (b) total transmittance during the drift of Tara in 2007 (Nicolaus et al., 2010b). Compared are in situ measurements (green) with the presented method (red) and the presented method, but using the observed dates for phase transitions. Between 16 July and 14 August (dotted lines), a comparison is not reasonable, since the sensor was strongly influenced by biological processes during Tara.

around $0.5 \mathrm{Wm}^{-2}$, for both the calculated and measured time series. Afterwards, until the end of June, the measured transmitted fluxes increased steadily towards $10 \mathrm{Wm}^{-2}$, whereas calculated fluxes were highly variable, with most values below $4 \mathrm{Wm}^{-2}$. Hence, the total solar heat input through the sea ice to the ocean from 1 May to 16 July 2007 was $21.4 \mathrm{MJ} \mathrm{m}^{-2}$ for the observed Tara data, whereas the calculated data resulted in a $17 \%$ lower total heat flux of $17.7 \mathrm{MJ} \mathrm{m}^{-2}$. The calculated underestimation is equivalent to $1 \mathrm{~cm}$ of sea ice melt for this period. During summer (16 July to 14 August 2007), under-ice fluxes cannot be reliably compared, since the sensor at the Tara study was strongly influenced by biological processes in ice and water, causing increased absorption and reduced transmitted fluxes. Thus, the calculated fluxes were overestimated by $11.6 \mathrm{MJ} \mathrm{m}^{-2}$, representing an equivalent sea ice melt of $4 \mathrm{~cm}$ during summer.

After 14 August, the measured transmitted heat flux increased rapidly to about $6 \mathrm{Wm}^{-2}$, comparable to the calculated value. Finally, the decrease in solar elevation caused decreasing transmitted fluxes in both data sets, resulting in similar heat fluxes of $0.28 \times 10^{3} \mathrm{MJ} \mathrm{m}^{-2}$ after 14 August.

The main reason for these differences is the timing of the phases describing the surface characteristics. While both data sets have a coincident EMO on 9 June, large differences are evident for the later phase transitions: the observed MO at Tara was on 21 June, whereas the calculated MO for the center position was 17 days later on 8 July. Considering the eight neighboring cells results in a mean MO on 13 June. This shows that there is a difference of 25 days in MO for the $10 \mathrm{~km}$ grid. As presented above, the transmitted heat flux depends strongly on the timing of the different melt phases by Markus et al. (2009). EFO was observed on 15 August during Tara, whereas the satellite data maintain summer melt conditions until 14 September. However, the total solar heat input through sea ice was similar for both data sets. Thus, the solar radiation flux under Arctic sea ice depends strongly on the timing of EMO and MO, while the timing of EFO and FO seems to be of less importance, since the beginning of the melt season coincides with maximum surface solar heat fluxes. The timing of melt onset also has a large influence on the total amount of light absorption, as shown in Stroeve et al. (2014). Including the ongoing lengthening of the melt season by up to 2 weeks per decade (by a later EMO), Stroeve et al.'s (2014) calculations suggest an albedo decrease of $9 \%$ per decade.

In a second validation step, the heat fluxes were recalculated using the onset dates as observed during Tara instead of those by Markus et al. (2009) (Fig. 6, black lines). This eliminated the impact of the onset dates on the results. Nevertheless, the calculated total solar heat input through sea ice still differed by $18 \%\left(25.4 \mathrm{MJ} \mathrm{m}^{-2}\right)$ from the Tara fluxes until 16 July (Fig. 6a), due to an unexpected peak in $Q_{\mathrm{T}}(x, y)$ in July. In addition, the calculated time series still showed large day-to-day variability, including much higher transmittance values than observed at Tara. The main reason for this is the combination of both sea ice types (FYI and MYI), whereas the Tara floe consisted of MYI only. Consequently, the strong differences in optical properties of FYI and MYI, as parameterized here, strongly contribute to the overall energy budget. To overcome this problem, FYI/MYI fractions per grid cell (Kwok, 2004) could be used instead of 
the presented discrete distinction. However, such a data set is not yet available for the given time span.

Hudson et al. (2013) measured heat fluxes and calculated transmittance values of Arctic FYI in July/August 2012. However, a direct comparison of energy fluxes, as for the Tara measurements, is not possible, because the melt-pond concentration data set ends in December 2011. August transmittance in our study (0.087) is based on the observations by Nicolaus et al. (2012), which is only half of the 0.16 found by Hudson et al. (2013). Hence, it may be assumed that heat fluxes through sea ice would be larger, based on those measurements. Differences between both studies mainly result from differences in sea ice thickness during the respective campaigns as well as the different methods of quantifying transmittance (mean value vs. modal value) (Hudson et al., 2013).

\subsection{Limitations}

Measurements from ice-tethered profilers (ITPs) (Krishfield et al., 2008) could be used as an alternative approach to estimate uncertainties of the new parameterization. They allow quantifcation of the heat content of the uppermost ocean and its changes. However, such a comparison would require a significant extension of the present study, integrating radiation fluxes to larger depths and through open water. Similarly, the inclusion of a radiation transfer model is beyond the aim of this study. The advantage of this study is the rather simplistic approach based on a seasonal parameterization of under-ice fluxes applied to existing large-scale data products.

An improvement to this study would be the inclusion of sea ice thickness (e.g., CryoSat-2, IceSat, OperationIceBridge) and snow depth (e.g., AMSR-E) observations from satellites. As with all other input data, the above-mentioned products need to be consistent over many years and reliable during all seasons. However, this is not the case yet, and even the most recent data sets have huge uncertainties or are not available after melt onset (e.g., Ricker et al., 2014), which is the most important time with respect to transmitted heat fluxes. Hence, these parameters are not applicable for such parameterizations yet. Instead, sea ice age is used as a proxy for ice thickness and snow depth distribution. It also includes information about roughness and deformation of the sea ice surface. These characteristics are crucial for the description of optical properties of sea ice.

In addition, including data sets of different model simulations, such as sea ice thickness, snow depth, and melt pond fraction (e.g., Flocco et al., 2012; Schröder et al., 2014), can be considered to be an alternative approach for the presented calculations.

Another uncertainty in the presented heat flux calculations results from constant values for the transmittance of melt ponds on FYI and MYI. Based on our existing data, it was not possible to include a seasonality in melt pond transmittances, which represents the different formation and evolution stages (Perovich and Polashenski, 2012). However, the applied transmittances of melt ponds are modal values of a distribution function (Nicolaus et al., 2012), representing a range of possible values. This has to be considered when comparing our fluxes to other observations or model results. Overall, we expect that the uncertainties resulting from the missing seasonal cycle will have a much smaller impact than the timing of melt onset, which is discussed in the next section.

\subsection{Sensitivity studies}

Based on uncertainties of the independent input variables (timing and length of the melt season, ice age, and melt pond fraction), several sensitivity studies have been performed to estimate the uncertainty for the presented parameterization.

The first study studies the effect of altering the timing and duration of the melt season on the solar heat input to the upper ocean. Three cases are discussed: shifting the melt season dates by (Case 1a) the average uncertainty of 4 days, as given by Markus et al. (2009), (Case 1b) 7 days based on the temporal resolution of ice age data (once per week) (Maslanik et al., 2011), and (Case 1c) (averaged) 14 days, as derived from comparisons with the Tara field data (Nicolaus et al., 2010a). Based on the observed ongoing trend towards a lengthening of the melt season, all sensitivity studies were only performed for earlier EMO and MO, and a later EFO and FO for the exemplary year of 2011.

Extending the melt season by 4 days (Case 1a) results in Arctic-wide mean EMO on 12 May and MO on 27 May. This affects most regions primarily during periods of high sea ice concentration and large surface solar irradiance. It results in an increase in total annual solar heat input through sea ice to the ocean $\left(Q_{\mathrm{T}}\right)$ of $7 \%$, from $53.3 \times 10^{19} \mathrm{~J}$ to $57.0 \times 10^{19} \mathrm{~J}$, for the entire year of 2011. The strongest increase of $20 \%$ compared to the reference melt onset dates was found in May, while the strongest absolute increase of $1.9 \times 10^{19} \mathrm{~J}$ was found in June.

Including 7 days earlier EMO and MO (8 May and 23 May, respectively) (Case $1 \mathrm{~b}$ ) result in an additional heat input of $5.9 \times 10^{19} \mathrm{~J}(+11 \%)$ compared to the reference system for the total annual heat input to the upper ocean. Shifting the melt season another 7 days (Case 1c) backwards ( 1 and 16 May), the increase in $Q_{\mathrm{T}}$ is more than double compared to the 7 -day shift (Table $3,66.3 \times 10^{19} \mathrm{~J}$ ). The pronounced increase is most evident in May, when $90 \%$ more light transmission was found than in the reference system. The strongest absolute increase of $6.2 \times 10^{19} \mathrm{~J}$ (transmittance from 0.054 to 0.067 ) was calculated for June. The spatial distribution in the impact of the 14-day earlier EMO and MO showed the largest increase in solar heat input to the upper ocean in the marginal ice zone, with increases greater than $100 \%$ (Fig. 7a).

Extending the melt season by 14 days later EFO and FO (Case 1c) (21 October and 2 November, respectively) result 
Table 3. Annual Arctic-wide solar heat input (and relative changes) under sea ice $\left(Q_{\mathrm{T}}\right)$ in 2011 for the reference method and sensitivity study 1: changes in melt season duration by a shift of 4 days (data uncertainty, Markus et al., 2009), 7 days (estimated uncertainty due to the only weekly sea ice age data by Maslanik et al., 2011), and 14 days (derived from comparisons to field data; Nicolaus et al., 2010a). All trends were only performed towards a prolongation of the melt season. All numbers are in $10^{19} \mathrm{~J}$.

\begin{tabular}{|c|c|c|c|c|c|c|c|}
\hline & \multirow{2}{*}{$\begin{array}{c}\text { Reference } \\
\text { system }\end{array}$} & \multicolumn{3}{|c|}{ Changing EMO and MO } & \multicolumn{3}{|c|}{ Changing EFO and FO } \\
\hline & & -4 days & -7 days & -14 days & +4 days & +7 days & +14 days \\
\hline Apr & 1.00 & $1.17(+17 \%)$ & $1.19(+19 \%)$ & $1.45(+45 \%)$ & $1.00(0 \%)$ & $1.00(0 \%)$ & $1.00(0 \%)$ \\
\hline May & 5.53 & $6.64(+20 \%)$ & $7.35(+33 \%)$ & $10.5(+90 \%)$ & $5.53(0 \%)$ & $5.53(0 \%)$ & $5.53(0 \%)$ \\
\hline Jun & 20.9 & $22.8(+9 \%)$ & $24.0(+15 \%)$ & $27.1(+30 \%)$ & $20.9(0 \%)$ & $20.9(0 \%)$ & $20.9(0 \%)$ \\
\hline Jul & 18.4 & $18.7(+2 \%)$ & $19.1(+4 \%)$ & $19.7(+7 \%)$ & $18.4(0 \%)$ & $18.4(0 \%)$ & $18.4(0 \%)$ \\
\hline Aug & 6.33 & $6.34(0 \%)$ & $6.42(+1 \%)$ & $6.48(+2 \%)$ & $6.46(+2 \%)$ & $6.51(+3 \%)$ & $6.68(+5 \%)$ \\
\hline Sep & 0.69 & $0.69(0 \%)$ & $0.69(0 \%)$ & $0.69(0 \%)$ & $0.74(+7 \%)$ & $0.81(+17 \%)$ & $0.97(+41 \%)$ \\
\hline Jan-Dec & 53.3 & $57.0(+7 \%)$ & $59.2(+11 \%)$ & $66.3(+24 \%)$ & $53.4(0 \%)$ & $53.6(+0 \%)$ & $53.9(+1 \%)$ \\
\hline
\end{tabular}
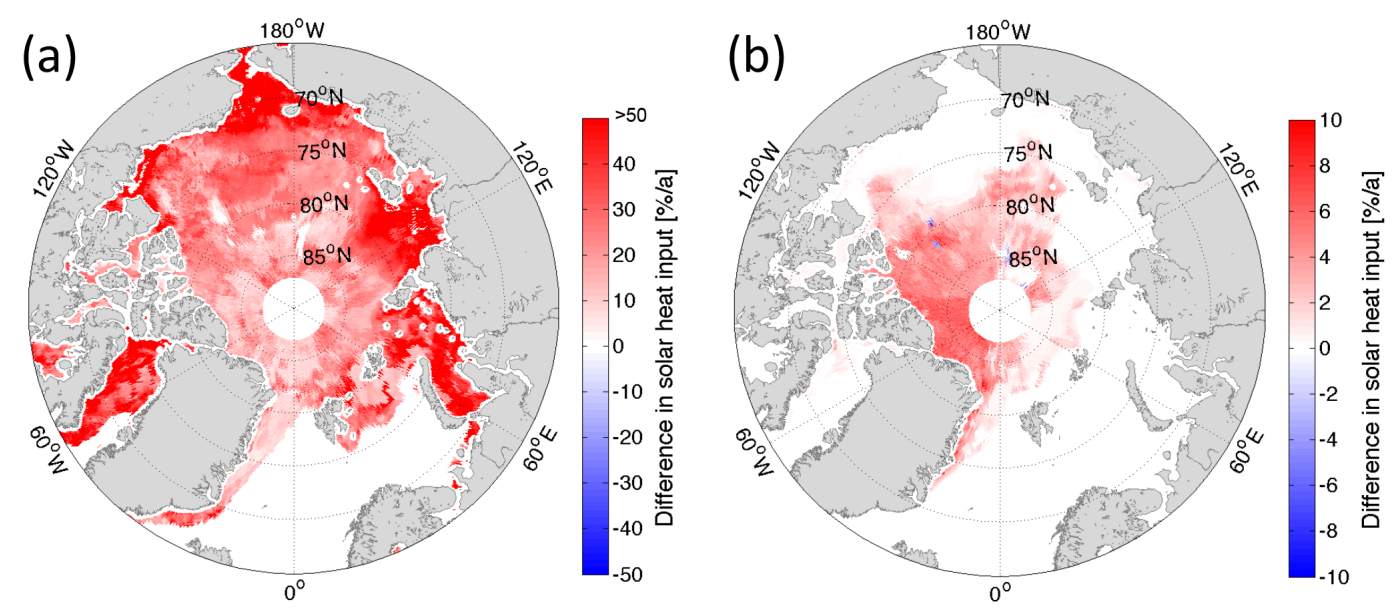

Figure 7. Changes in annual total solar heat input $\left(Q_{\mathrm{T}}(x, y)\right)$ through sea ice in 2011, resulting from a sensitivity study assuming an extended melt season. (a) 14 days earlier early melt onset and melt onset, and (b) 14 days later early freeze onset and freeze onset than in the reference method, based on Markus et al. (2009).

in a $1 \%$ increase in $Q_{\mathrm{T}}$ from $53.3 \times 10^{19} \mathrm{~J}$ to $53.9 \times 10^{19} \mathrm{~J}$ (Fig. 7b). Since the surface solar radiation is much less than between April and June, the change at the end of the melt season is small during August and September (increase of $9 \%$ from $7.02 \times 10^{19} \mathrm{~J}$ to $7.65 \times 10^{19} \mathrm{~J}$ ). Seven-day or rather four-day (cases 1a and 1b) later EFO and FO have a negligible effect on the total annual transmitted heat flux of less than $1 \%$.

In a second sensitivity study, the influence of the ice type was quantified. As the sea ice type data contain no uncertainty, the study is based on the ongoing trend towards a predominantly FYI-covered Arctic Ocean. The reference ice cover of 2011 consists of $56 \%$ FYI and 44\% MYI in August 2011. Assuming that all sea ice in 2011 was MYI, the mean transmitted flux decreased by $34 \%$ to $35.5 \times 10^{19} \mathrm{~J}$. In contrast, assuming that only FYI was present increased the mean transmitted flux by $18 \%$, to $62.7 \times 10^{19} \mathrm{~J}$. Hence, the transition from an MYI- to FYI-dominated Arctic sea ice regime results in a further increase in solar heat flux under Arctic sea ice.

The third sensitivity study investigates the effects of melt pond fraction uncertainties. Here, we consider two cases: (Case 3a) Rösel et al. (2012) give a mean uncertainty of $3 \%$, and (Case 3b) we estimate an uncertainty of $20 \%$ due to the neglected seasonal cycle. Adapting these assumptions, an increasing melt pond fraction of $3 \%(20 \%)$ results in an increase in the transmitted heat flux of $1 \%(9 \%)$.

Uncertainties in the solar surface radiation and sea ice concentration are not analyzed through additional sensitivity studies, because they impact the results linearly (Eq. 2).

\section{Summary and conclusions}

The presented parameterization for light transmission through Arctic sea ice in combination with satellite-derived time series observations and re-analysis data allowed the 
quantification of solar short-wave radiation fluxes through Arctic sea ice for the entire annual cycle over 33 years (1979 to 2011). The presented results suggest that $96 \%$ of the total annual solar heat input through sea ice occurs over only 4 months (May to August), with the highest transmitted fluxes calculated for June. Over the time period 1979 to 2011, an increase in light transmission of $1.5 \% \mathrm{yr}^{-1}$ with regional maxima of $4.0 \%$ was found. Hence, the amount of shortwave radiation that may contribute to sea ice bottom melt increased by $63 \%$ over this 33-year period. The results of our sensitivity studies show that energy fluxes depend strongly on the timing of melt onset, sea ice types (first- and multiyear ice), and melt pond fraction. These are the most critical parameters for the presented calculations, and describe the most critical uncertainties. The calculated trends are affected by most of these uncertainties.

This study considers the fluxes through ice-covered ocean regions only. This highlights the fact that changes in sea ice properties have a large impact on the sea ice and upper ocean energy budget, and that this impact adds to the obvious increase in energy input resulting from the observed decrease in ice-covered areas (open ocean effect). However, the ongoing retreat of sea ice will cause additional increases in radiation fluxes into the Arctic Ocean. The additional heat will also contribute to an increase in heat stored in the ocean mixed layer, and will impact the melt season duration and timing, particularly during autumn freeze-up.

A comparison of trends in solar heat fluxes into the sea ice by Perovich et al. (2011a) with our calculated solar heat fluxes through sea ice suggests similar increases in transmitted and absorbed energy. This additional energy input into the sea ice and the upper ocean would also impact inner sea ice structures as well as internal and basal melting. Studies from Perovich et al. (2011a) and Nicolaus et al. $(2012,2013)$ reveal that fluxes through open water clearly dominate the transmitted heat flux signal and, therefore, the effect of sea ice concentration becomes most obvious. Since our presented study focuses on changes in physical properties of sea ice and its effects, all calculated trends are corrected for the trend in sea ice concentration, and fluxes through open water are neglected. Also, the effects of heat convection and advection as well as lateral heat fluxes are not discussed, due to the limited number of recent studies on that topic.

More investigations of bio-geo-physical interactions are needed to quantify better the effects of the changing physical environment on the ecosystem and element cycles, and vice versa. Additional work is also required to improve Arctic-wide snow depth and sea ice thickness data products. Those products should provide a good description of surface properties during the spring-summer transition, when the largest uncertainties were found. Such time series might become available from new data products that merge observations from different satellites and sensor types (e.g., SMOS, CryoSat-2, AMSR-E), and potentially also numerical models. The non-existence of such reliable long-term and Arctic-wide data sets was the main motivation for developing the presented method, based on available parameters. Otherwise, the application of a radiation transfer model with adequate input (forcing) data would have been an obvious alternative.

Acknowledgements. We are most grateful to Jim Maslanik (University of Colorado Boulder), Thorsten Markus and Jeffrey Miller (both NASA Goddard Space Flight Center), Thomas Lavergne (OSISAF, Met Norway), and Anja Rösel and Larsch Kaleschke (both University of Hamburg) for data provision and support through manifold discussions on their data products and processing details. We thank Christian Katlein (Alfred-Wegener-Institut HelmholtzZentrum für Polar- und Meeresforschung) and Martin Claussen (Max Planck Institute for Meteorology) for constructive comments on the manuscript, as well as Benjamin Lange (Alfred-WegenerInstitut Helmholtz-Zentrum für Polar- und Meeresforschung) for proofreading. We appreciate the efforts of the three anonymous reviewers and the scientific editor in improving the manuscript. The study was funded through the Remote Sensing Alliance of the Helmholtz Association and the Alfred-Wegener-Institut Helmholtz-Zentrum für Polar- und Meeresforschung.

Edited by: R. Lindsay

\section{References}

Andersen, S., Breivik, L. A., Eastwood, S., Godøy, Ø., Lind, M., Porcires, M., and Schyberg, H.: OSI SAF Sea Ice Product Manual v3. 5, Tech. Rep. SAF/OSI/met. no/TEC/MA/125, EUMETSAT OSI SAF, Ocean and Sea Ice Sattelite Application Facility, 2007.

Arrigo, K. R., Perovich, D. K., Pickart, R. S., Brown, Z. W., van Dijken, G. L., Lowry, K. E., Mills, M. M., Palmer, M. A., Balch, W. M., Bahr, F., Bates, N. R., Benitez-Nelson, C., Bowler, B., Brownlee, E., Ehn, J. K., Frey, K. E., Garley, R., Laney, S. R., Lubelczyk, L., Mathis, J., Matsuoka, A., Mitchell, B. G., Moore, G. W. K., Ortega-Retuerta, E., Pal, S., Polashenski, C. M., Reynolds, R. A., Schieber, B., Sosik, H. M., Stephens, M., and Swift, J. H.: Massive Phytoplankton Blooms Under Arctic Sea Ice, Science, 336, 1408-1408, doi:10.1126/Science.1215065, 2012.

Barber, D. G., Fung, A. K., Grenfell, T. C., Nghiem, S. V., Onstott, R. G., Lytle, V. I., Perovich, D. K., and Gow, A. J.: The role of snow on microwave emission and scattering over first-year sea ice, IEEE T. Geosci. Remote, 36, 1750-1763, doi:10.1109/36.718643, 1998.

Comiso, J. C.: Large decadal decline of the Arctic multiyear ice cover, J. Climate, 25, 1176-1193, 2012.

Deal, C., Jin, M. B., Elliott, S., Hunke, E., Maltrud, M., and Jeffery, N.: Large-scale modeling of primary production and ice algal biomass within arctic sea ice in 1992, J. Geophys. Res.-Oceans, 116, C07004, doi:10.1029/2010jc006409, 2011.

Dee, D. P., Uppala, S. M., Simmons, A. J., Berrisford, P., Poli, P., Kobayashi, S., Andrae, U., Balmaseda, M. A., Balsamo, G., and Bauer, P.: The ERA-Interim reanalysis: Configuration and 
performance of the data assimilation system, Q. J. Roy. Meteorol. Soc., 137, 553-597, 2011.

Flocco, D., Schroeder, D., Feltham, D. L., and Hunke, E. C.: Impact of melt ponds on Arctic sea ice simulations from 1990 to 2007, J. Geophys. Res.-Oceans, 117, C09032, doi:10.1029/2012jc008195, 2012.

Frey, K. E., Perovich, D. K., and Light, B.: The spatial distribution of solar radiation under a melting Arctic sea ice cover, Geophys. Res. Lett., 38, L22501, doi:10.1029/2011g1049421, 2011.

Grenfell, T. C., Light, B., and Perovich, D. K.: Spectral transmission and implications for the partitioning of shortwave radiation in arctic sea ice, Ann. Glaciol., 44, 1-6, 2006.

Haas, C., Pfaffling, A., Hendricks, S., Rabenstein, L., Etienne, J. L., and Rigor, I.: Reduced ice thickness in Arctic Transpolar Drift favors rapid ice retreat, Geophys. Res. Lett., 35, L17501, doi:10.1029/2008g1034457, 2008.

Hudson, S. R., Granskog, M. A., Sundfjord, A., Randelhoff, A., Renner, A. H. H., and Divine, D. V.: Energy budget of first-year Arctic sea ice in advanced stages of melt, Geophys. Res. Lett., 40, 2679-2683, doi:10.1002/Grl.50517, 2013.

Katlein, C., Nicolaus, M., and Petrich, C.: The anisotropic scattering coefficient of sea ice, J. Geophys. Res.-Oceans, 119, 842-855, doi:10.1002/2013jc009502, 2014.

Krishfield, R., Toole, J., Proshutinsky, A., and Timmermans, M. L.: Automated Ice-Tethered Profilers for Seawater Observations under Pack Ice in All Seasons, J. Atmos. Ocean. Tech., 25, 2091-2105, doi:10.1175/2008jtecho587.1, 2008.

Kwok, R.: Annual cycles of multiyear sea ice coverage of the Arctic Ocean: 1999-2003, J. Geophys. Res., 109, C11004, doi:10.1029/2003JC002238, 2004.

Lavergne, T., Killie, M. A., Eastwood, S., and Breivik, L.-A.: Extending the CryoClim Arctic sea ice extent time series with operational OSI SAF products from 2008 onwards, Norwegian Meteorological Institute note 7, Norwegian Meteorological Institute, Oslo, 2010.

Leu, E., Wiktor, J., Soreide, J. E., Berge, J., and Falk-Petersen, S.: Increased irradiance reduces food quality of sea ice algae, Mar. Ecol. Prog.-Ser., 411, 49-60, doi:10.3354/Meps08647, 2010.

Light, B., Grenfell, T. C., and Perovich, D. K.: Transmission and absorption of solar radiation by Arctic sea ice during the melt season, J. Geophys. Res.-Oceans, 113, C03023, doi:10.1029/2006jc003977, 2008.

Lindsay, R., Wensnahan, M., Schweiger, A., and Zhang, J.: Evaluation of Seven Different Atmospheric Reanalysis Products in the Arctic, J. Climate, 27, 2588-2606, doi:10.1175/Jcli-D-13$00014.1,2014$.

Markus, T., Stroeve, J. C., and Miller, J. A.: Recent changes in Arctic sea ice melt onset, freezeup, and melt season length, J. Geophys. Res., 114, C12024, doi:10.1029/2009jc005436, 2009.

Maslanik, J. A., Fowler, C., Stroeve, J., Drobot, S., Zwally, J., Yi, D., and Emery, W.: A younger, thinner Arctic ice cover: Increased potential for rapid, extensive sea-ice loss, Geophys. Res. Lett., 34, L24501, doi:10.1029/2007g1032043, 2007.

Maslanik, J. A., Stroeve, J., Fowler, C., and Emery, W.: Distribution and trends in Arctic sea ice age through spring 2011, Geophys. Res. Lett., 38, L13502, doi:10.1029/2011g1047735, 2011.

Mundy, C. J., Barber, D. G., and Michel, C.: Variability of snow and ice thermal, physical and optical properties pertinent to sea ice algae biomass during spring, J. Mar. Syst., 58, 107-120, doi:10.1016/J.Jmarsys.2005.07.003, 2005.

Mundy, C. J., Ehn, J. K., Barber, D. G., and Michel, C.: Influence of snow cover and algae on the spectral dependence of transmitted irradiance through Arctic landfast first-year sea ice, J. Geophys. Res.-Oceans, 112, C03007, doi:10.1029/2006jc003683, 2007.

Nicolaus, M., Haas, C., Bareiss, J., and Willmes, S.: A model study of differences of snow thinning on Arctic and Antarctic first-year sea ice during spring and summer, Ann. Glaciol., 44, 147-153, 2006.

Nicolaus, M., Gerland, S., Hudson, S. R., Hanson, S., Haapala, J., and Perovich, D. K.: Seasonality of spectral albedo and transmittance as observed in the Arctic Transpolar Drift in 2007, J. Geophys. Res.-Oceans, 115, C11011, doi:10.1029/2009jc006074, 2010a.

Nicolaus, M., Hudson, S. R., Gerland, S., and Munderloh, K.: A modern concept for autonomous and continuous measurements of spectral albedo and transmittance of sea ice, Cold Reg. Sci. Technol., 62, 14-28, 2010b.

Nicolaus, M., Katlein, C., Maslanik, J., and Hendricks, S.: Changes in Arctic sea ice result in increasing light transmittance and absorption, Geophys. Res. Lett., 39, L24501, doi:10.1029/2012gl053738, 2012.

Nicolaus, M., Arndt, S., Katlein, C., Maslanik, J., and Hendricks, S.: Correction to "Changes in Arctic sea ice result in increasing light transmittance and absorption”, Geophys. Res. Lett., 40, 2699-2700, doi:10.1002/grl.50523, 2013.

Perovich, D. K.: The Optical Properties of Sea Ice, US Cold Reg. Res. and Eng. Lab. Monogr., Hannover, 25 pp., 1996.

Perovich, D. K.: On the aggregate-scale partitioning of solar radiation in Arctic sea ice during the Surface Heat Budget of the Arctic Ocean (SHEBA) field experiment, J. Geophys. Res.-Oceans, 110, C03002, doi:10.1029/2004jc002512, 2005.

Perovich, D. K. and Polashenski, C.: Albedo evolution of seasonal Arctic sea ice, Geophys. Res. Lett., 39, L08501, doi:10.1029/2012g1051432, 2012.

Perovich, D. K. and Richter-Menge, J. A.: Loss of Sea Ice in the Arctic, Annu. Rev. Mar. Sci., 1, 417-441, 2009.

Perovich, D. K., Roesler, C. S., and Pegau, W. S.: Variability in Arctic sea ice optical properties, J. Geophys. Res.-Oceans, 103, 1193-1208, doi:10.1029/97jc01614, 1998.

Perovich, D. K., Grenfell, T. C., Light, B., and Hobbs, P. V.: Seasonal evolution of the albedo of multiyear Arctic sea ice, J. Geophys. Res.-Oceans, 107, 8044, doi:10.1029/2000jc000438, 2002.

Perovich, D. K., Light, B., Eicken, H., Jones, K. F., Runciman, K., and Nghiem, S. V.: Increasing solar heating of the Arctic Ocean and adjacent seas, 1979-2005: Attribution and role in the ice-albedo feedback, Geophys. Res. Lett., 34, L19505, doi:10.1029/2007GL031480, 2007a.

Perovich, D. K., Nghiem, S. V., Markus, T., and Schweiger, A.: Seasonal evolution and interannual variability of the local solar energy absorbed by the Arctic sea ice-ocean system, J. Geophys. Res.-Oceans, 112, C03005, doi:10.1029/2006jc003558, 2007b.

Perovich, D. K., Jones, K. F., Light, B., Eicken, H., Markus, T., Stroeve, J., and Lindsay, R.: Solar partitioning in a changing Arctic sea-ice cover, Ann. Glaciology, 52, 192-196, 2011a.

Perovich, D. K., Richter-Menge, J. A., Jones, K. F., Light, B., Elder, B. C., Polashenski, C., Laroche, D., Markus, T., and Lindsay, R.: 
Arctic sea-ice melt in 2008 and the role of solar heating, Ann. Glaciol., 52, 355-359, 2011 b.

Popova, E. E., Yool, A., Coward, A. C., Dupont, F., Deal, C., Elliott, S., Hunke, E., Jin, M. B., Steele, M., and Zhang, J. L.: What controls primary production in the Arctic Ocean? Results from an intercomparison of five general circulation models with biogeochemistry, J. Geophys. Res.-Oceans, 117, C00d12, doi:10.1029/2011jc007112, 2012.

Ricker, R., Hendricks, S., Helm, V., Skourup, H., and Davidson, M.: Sensitivity of CryoSat-2 Arctic sea-ice freeboard and thickness on radar-waveform interpretation, The Cryosphere, 8 , 1607-1622, doi:10.5194/tc-8-1607-2014, 2014.

Rösel, A. and Kaleschke, L.: Exceptional melt pond occurrence in the years 2007 and 2011 on the Arctic sea ice revealed from MODIS satellite data, J. Geophys. Res.-Oceans, 117, C05018, doi:10.1029/2011jc007869, 2012.

Rösel, A., Kaleschke, L., and Birnbaum, G.: Melt ponds on Arctic sea ice determined from MODIS satellite data using an artificial neural network, The Cryosphere, 6, 431-446, doi:10.5194/tc-6431-2012, 2012.
Schröder, D., Feltham, D. L., Flocco, D., and Tsamados, M.: September Arctic sea-ice minimum predicted by spring melt-pond fraction, Nat. Clim. Change, 4, 353-357, doi:10.1038/nclimate2203, 2014.

Stroeve, J. C., Markus, T., Boisvert, L., Miller, J., and Barrett, A.: Changes in Arctic melt season and implications for sea ice loss, Geophys. Res. Lett., 41, 1216-1225, doi:10.1002/2013g1058951, 2014.

Wang, C., Granskog, M. A., Gerland, S., Hudson, S. R., Perovich, D. K., Nicolaus, M., Ivan Karlsen, T., Fossan, K., and Bratrein, M.: Autonomous observations of solar energy partitioning in first-year sea ice in the Arctic Basin, J. Geophys. Res.-Oceans, 119, 2066-2080, 2014.

Wassmann, P. and Reigstad, M.: Future Arctic Ocean Seasonal Ice Zones and Implications for Pelagic-Benthic Coupling, Oceanography, 24, 220-231, doi:10.5670/oceanog.2011.74, 2011. 